\title{
Bacterial carbon content and the living and detrital bacterial contributions to suspended particulate organic carbon in the North Pacific Ocean
}

\author{
Nobuyuki Kawasaki ${ }^{1,2, *}$, Rumi Sohrin ${ }^{3}$, Hiroshi Ogawa ${ }^{4}$, Toshi Nagata ${ }^{4}$, \\ Ronald Benner ${ }^{1}$ \\ ${ }^{1}$ University of South Carolina, Marine Science Program, Columbia, South Carolina 29208, USA \\ ${ }^{2}$ National Institute for Environmental Studies, 16-2 Onogawa Tsukuba, Ibaraki 305-8506, Japan \\ ${ }^{3}$ Shizuoka University, 836 Ohya Shizuoka, Shizuoka 422-8529, Japan \\ ${ }^{4}$ Atmosphere and Ocean Research Institute, University of Tokyo, 5-1-5 Kashiwanoha, Kashiwa, Chiba 277-8564, Japan
}

\begin{abstract}
Carbon-normalized yields of amino acids in size-fractionated seawater samples and bacterial cultures were used in a novel application to estimate the carbon content of heterotrophic marine bacteria. The estimated carbon content $\left(6.3 \pm 1.6 \mathrm{fg} \mathrm{C} \mathrm{cell}^{-1}\right)$ of open ocean bacteria derived using this approach was lower than most values estimated in previous studies. Based on these values, living heterotrophic bacteria accounted for $6.8 \pm 1.1 \%$ of suspended particulate organic carbon (POC) in surface waters at Stn ALOHA in the North Pacific gyre. Living cyanobacteria accounted for $13.3 \pm$ $2.2 \%$ of suspended POC in surface waters. Carbon-normalized yields of muramic acid, D-alanine and D-glutamic acid, unique biomarkers of bacteria, were used to estimate that bacterial detritus accounted for $4.3 \pm 2.9 \%$ of suspended POC in surface waters. The relative contribution of bacterial detritus to suspended POC increased dramatically with increasing depth, indicating that some components of bacterial detritus are resistant to decomposition in the deep ocean. The total living and detrital bacterial contribution to suspended POC in surface waters was $\sim 25 \%$.
\end{abstract}

KEY WORDS: Bacterial carbon content - Bacterial detritus - Bacterial biomarkers · Suspended particulate organic carbon

\section{INTRODUCTION}

Cyanobacteria and heterotrophic bacteria play major roles in marine biogeochemical cycles. Cyanobacteria are dominant primary producers in many open ocean environments (Fogg 1986, Letelier et al. 1993). For example, Prochlorococcus comprises $~ 40 \%$ of autotrophs (Letelier et al. 1993, Liu et al. 1995) and up to $30 \%$ of total bacterial counts (Campbell et al. 1994) in the surface waters of the ocean at Stn ALOHA in the subtropical North Pacific. Heterotrophic bacteria play critical roles in the transformation and remineralization of organic matter in aquatic environments, and it is estimated that about half of the photosynthetic production in the ocean is processed by heterotrophic bacteria in the microbial loop (Ducklow 2000).
In oligotrophic regions, the autotrophic and heterotrophic bacterial biomass is reported to account for a large fraction of suspended particulate organic carbon (POC). Campbell et al. (1994) reported that cyanobacteria and heterotrophic bacteria contribute equally ( 25 to $30 \%$ each) to POC in the surface mixed layer of the North Pacific gyre. Cho \& Azam (1988) and Fuhrman et al. (1989) reported that carbon biomass of heterotrophic bacteria accounts for a large (40 to $80 \%$ ) fraction of POC in surface and deep waters of the open ocean. These studies estimated bacterial biomass from measurements of bacterial abundance and estimates of bacterial carbon content, with typical values of carbon content ranging from 15 to $20 \mathrm{fg} \mathrm{C}$ cell $^{-1}$ for heterotrophic bacteria (Cho \& Azam 1988, Fuhrman et al. 1989, Caron et al. 1995), and from 30 to $60 \mathrm{fg} \mathrm{C} \mathrm{cell}^{-1}$ for 
Prochlorococcus (Partensky et al. 1999) and $\sim 250 \mathrm{fg}$ C cell $^{-1}$ for Synechococcus (Kana \& Glibert 1987).

A variety of approaches have been used to measure the carbon content of marine bacteria, and estimated values vary widely, particularly for heterotrophic bacteria. The carbon content of heterotrophic bacteria in the open ocean is estimated to be as low as 2 to $9 \mathrm{fg} C$ cell $^{-1}$ (Christian \& Karl 1994, Gundersen et al. 2002). Estimates of bacterial biomass and biological carbon inventories in the oceans are dependent on estimates of bacterial carbon content, and it is not entirely clear whether the observed variability in bacterial carbon is due to regional differences in bacterial communities or to methodological artifacts in the derivation of bacterial carbon content, or both.

Fukuda et al. (1998) reported the first direct measurements of the carbon content of marine heterotrophic bacteria. Particles of the size of heterotrophic bacteria (prokaryotes), between 0.1 and $\sim 0.8 \mu \mathrm{m}$, were separated from other organisms and particles in surface waters using tangential-flow ultrafiltration. The carbon content of the concentrated materials was measured by hightemperature combustion, and bacteria were stained with 4', 6-diamidino-2-phenylindole (DAPI) and counted using epifluorescence microscopy. The average carbon content of heterotrophic bacteria in the open and coastal ocean was estimated to be 12.4 and $30.2 \mathrm{fg} \mathrm{C} \mathrm{Cell}^{-1}$, respectively. These values have been widely used during the past decade due to the direct nature of the measurements for natural assemblages of marine bacteria. However, the approach used by Fukuda et al. (1998) relied primarily on size to isolate bacteria, and it is possible that some detrital particles were included in these samples. Detrital particles in this size range are known to be abundant in seawater (Koike et al. 1990, Longhurst et al. 1992). Consequently, the reported bacterial carbon content could have been overestimated.

Proteins (amino acids) comprise about half of the carbon in bacteria (Simon \& Azam 1989, Neidhardt 1996, Kaiser \& Benner 2008). The percentage of total cellular carbon as amino acids is fairly constant (50 to $60 \%$ ) in marine heterotrophic bacteria regardless of cell size (Simon \& Azam 1989, Kaiser \& Benner 2008). Thus, amino acid carbon measurements in the bacterial size fraction of marine organic matter, such as that isolated by Fukuda et al. (1998), could be very useful for estimating bacterial cell carbon, assuming that cell carbon is about twice the carbon measured in amino acids. Amino acids are known to be rapidly degraded in marine detritus (Davis et al. 2009), so yields of amino acids would be depleted in isolated particles if detritus were present. This approach is used in the present study to provide independent estimates of the carbon content of heterotrophic bacteria for calculation of living bacterial contributions to suspended POC.
Muramic acid, D-alanine and D-glutamic acid are uniquely found in bacteria and are useful biomarkers of bacteria (McCarthy et al. 1998, Benner \& Kaiser 2003). The carbon-normalized yields of these biomarkers are more variable among bacteria than are amino acid yields (Kaiser \& Benner 2008), but the biomarkers are unambiguous indicators of bacterial origin whereas amino acids (i.e. the L-enantiomers) are not. These biomarkers, in combination with estimates of bacterial biomass, have been very useful for estimating bacterial contributions to marine detritus (Benner \& Kaiser 2003, Kaiser \& Benner 2008) and are used in the present study to estimate bacterial detritus in suspended POC at Stn ALOHA in the subtropical North Pacific.

\section{MATERIALS AND METHODS}

Sampling location and collection. The collection of seawater samples and incubation experiments were carried out during a cruise aboard the RV 'Kilo Moana' to the Hawaii Ocean Time Series (HOTS) Stn ALOHA $\left(22^{\circ} 45^{\prime} \mathrm{N}, 158^{\circ} \mathrm{W}\right)$ between March 5 and 14,2004 . All samples were collected using Niskin bottles mounted on a rosette sampler equipped with a CTD. Water samples were collected at depths of $5,20,30,50,80$, $150,300,500,750,1000,3000$ and $4000 \mathrm{~m}$. A vertical profile of the concentrations of particulate amino acids and muramic acid was constructed from 2 casts for the collection of surface ( 5 to $150 \mathrm{~m}$ ) and deep (300 to $4000 \mathrm{~m}$ ) water samples. Samples for particulate amino acids and muramic acid were collected using $0.22 \mu \mathrm{m}$ Supor filters (Pall) with low vacuum pressure $(<25 \mathrm{kPa})$. The Supor filters and filtration equipment were rinsed thoroughly with deionized water before use. At least $500 \mathrm{ml}$ of deionized water was passed through the filters before the sample was filtered. About 1 to 21 of seawater was filtered for each sample. Samples were immediately frozen at $-20^{\circ} \mathrm{C}$ until analysis.

Incubation experiments. Two experiments were conducted to examine the biochemical composition of marine bacteria at Stn ALOHA. Deep seawater was collected from $1200 \mathrm{~m}$ and filtered using a $0.2 \mu \mathrm{m}$ pore size polycarbonate filter (Nucleopore) with a low vacuum pressure $(<25 \mathrm{kPa})$. Surface seawater (5 $\mathrm{m}$ depth) was collected and filtered through a $0.8 \mu \mathrm{m}$ pore size polycarbonate filter (Nucleopore) to remove bacterial grazers. Deep and surface seawaters were mixed with a ratio of $90 \%$ deep and $10 \%$ surface water and poured into acid-washed 11 polycarbonate bottles. Glucose $(25 \mu \mathrm{M})$ was added to stimulate bacterial growth in both experiments. Each experiment was conducted with 3 replicates, and all bottles were incubated in the dark at room temperature $\left(\sim 20^{\circ} \mathrm{C}\right)$. Subsamples were 
taken for measurements of total organic carbon (TOC) and the abundance of bacteria and grazers after $6 \mathrm{~d}$ of incubation. Subsamples for particulate amino acids and muramic acid were collected on $0.22 \mu \mathrm{m}$ Supor filters as described above. About 100 to $150 \mathrm{ml}$ of seawater was filtered for each sample. Samples were immediately frozen at $-20^{\circ} \mathrm{C}$ until analysis.

The abundance of bacteria (i.e. prokaryotes) and grazers was determined by epifluorescence microscopy using the DAPI method (Porter \& Feig 1980). Subsamples of bacteria were stained with DAPI, then filtered through $0.2 \mu \mathrm{m}$ pore size black Millipore polycarbonate filters mounted on prewetted $0.45 \mu \mathrm{m}$ pore size Nucleopore membrafil cellulosic filters with a low vacuum pressure $(<25 \mathrm{kPa})$. Subsamples of grazers were stained on $0.4 \mu \mathrm{m}$ pore size black Millipore polycarbonate filters mounted on $0.8 \mu \mathrm{m}$ pore size Nucleopore membrafil cellulosic filters. At least 300 bacteria per sample were counted, and 40 fields were enumerated for the abundance of grazers.

Amino acid content of the bacterium-size fraction of marine particles. Measurements of amino acids in the bacterium-size fraction of seawater samples were conducted during a previous study by Fukuda et al. (1998) and are reported here for the first time. These samples were collected from the Pacific and Southern oceans during a cruise (Leg III-IV of KH-94-4, 10 January to 14 February 1995) on the RV 'Hakuho-maru'. In the Southern Ocean, water samples were collected at a depth of $40 \mathrm{~m}$ with a Niskin bottle. In the Pacific Ocean a diaphragm pump was used to collect water samples while the ship was steaming. The inlet of the pump was about $4 \mathrm{~m}$ below the surface. Surface coastal samples were collected from Tokyo Bay and Otsuchi Bay with a Van Dorn water sampler. Detailed filtration procedures for the collection of the bacterium-size fraction of particulate organic matter (POM) are given in Fukuda et al. (1998), but briefly, 100 to $600 \mathrm{l}$ of water were gravity-filtered through glass-fiber filters (GF/C; $1.2 \mu \mathrm{m}$ pore size) and GA-200 filters ( $0.7 \mu \mathrm{m}$ pore size) for the Tokyo Bay samples, and GF-75 filters $(0.3 \mu \mathrm{m}$ pore size) for all other stations. Oceanic and some Tokyo Bay samples were further filtered through a cartridge membrane filter (Micropore 8AU type BS, nominal pore size $0.8 \mu \mathrm{m}$ and $7 \times 25 \mathrm{~cm}$ size). The particles in the prefiltered seawater were concentrated to $\sim 100 \mathrm{ml}$ with a Pellicon tangential-flow filtration system (Millipore). After the concentrate had been recovered, a small volume of sodium chloride solution (ca. $200 \mathrm{ml}$ ) was flushed through the system several times to release bacteria adsorbed to the membrane. Negligible amounts of chlorophyll were detected in the isolated size fraction, indicating minimal contributions from phototrophic organisms (see Fukuda et al. (1998) for details).
Sample analysis. The D- and L- enantiomers of total particulate amino acids (TPAAs) in Stn ALOHA samples were determined using reverse-phase highperformance liquid chromatography (HPLC) and precolumn derivatization with $o$-phthaldialdehyde (OPA) and $N$-isobutyryl D- and L-cysteine (Kaiser \& Benner 2005). Particulate D- and L-amino acids (TPAAs) were hydrolyzed with $6 \mathrm{~mol} \mathrm{l}^{-1} \mathrm{HCl}$ at $110^{\circ} \mathrm{C}$ for $20 \mathrm{~h}$ in sealed ampoules. After hydrolysis, samples were diluted 3 times with Milli-Q (MQ) water and centrifuged to remove all particles. Then, $20 \mu \mathrm{l}$ of supernatant were dried with a stream of nitrogen gas to remove $\mathrm{HCl}$. Ascorbic acid $\left(0.12 \mu \mathrm{mol} \mathrm{l}^{-1}\right)$ was added to all samples before hydrolysis. Racemization of enantiomers during hydrolysis was corrected as described by Kaiser \& Benner (2005). Muramic acid (Mur) was hydrolyzed with $3 \mathrm{~mol} \mathrm{l}^{-1} \mathrm{HCl}$ at $100^{\circ} \mathrm{C}$ for $5 \mathrm{~h}$ in sealed ampoules. Ascorbic acid $\left(0.12 \mu \mathrm{mol} \mathrm{l^{-1 }}\right)$ was also added to all samples before hydrolysis. After hydrolysis, Mur was analyzed by reverse-phase HPLC and pre-column derivatization with OPA and $N$-isobutyryl-L-cysteine as described by Kaiser \& Benner (2008)

Samples of the bacterium-size class of suspended POM collected by Fukuda et al. (1998) were analyzed within 14 mo of collection for total combined amino acids (TCAAs) as the difference between total hydrolysable amino acids (THAAs) and free amino acids (FAAs), which accounted for 7 to $19 \%$ of THAAs. FAAs were measured by HPLC using the OPA method (Lindroth \& Mopper 1979), and THAAs were measured by HPLC after vapor-phase hydrolysis (Keil \& Kirchman 1991). Particulate organic carbon and nitrogen in the concentrated liquid samples were determined by the high-temperature combustion method (Fukuda et al. 1998).

Abundance of cyanobacteria and heterotrophic bacteria. In this study, several of our estimates relied upon literature values and data from the HOTS website. All abbreviations used for parameters are shown in Table 1. The concentrations of suspended POC and the abundance of heterotrophic bacteria $\left(\mathrm{BA}_{\mathrm{H}}\right)$, Prochlorococcus and Synechococcus in the upper $100 \mathrm{~m}$ at Stn ALOHA during February, March and April of 2004 ranged from 1.9 to $2.0 \mathrm{mmol} \mathrm{l}^{-1}, 2.6$ to $4.3 \times 10^{5}$ cells $\mathrm{ml}^{-1}, 0.8$ to $1.1 \times 10^{5}$ cells ml $\mathrm{m}^{-1}$ and 0.1 to $2.2 \times 10^{3}$ cells $\mathrm{ml}^{-1}$, respectively (http://hahana.soest.hawaii.edu/hot/ hot-dogs/bextraction.html). Because the abundance of Prochlorococcus was always 2 or 3 orders of magnitude larger than that of Synechococcus, the biomass contribution of Synechococcus to suspended POC was minor. Therefore, the contribution of cyanobacteria to POC was based on data for Prochlorococcus. The values for heterotrophic bacteria were corrected for archaeal contributions based on the data of Karner et al. (2001) and are $23 \%$ lower than values presented 
Table 1. Parameters, abbreviations and values used in various calculations of bacterial contributions to marine particulate organic carbon $(\mathrm{POC})$ at Stn ALOHA. Mur = muramic acid

\begin{tabular}{|c|c|c|c|}
\hline Parameter & Abbreviation & Values used & Source \\
\hline Carbon per cell of heterotrophic bacteria & $\mathrm{CPC}_{\mathrm{HB}}$ & $6.3 \mathrm{fg} \mathrm{C}$ cell $^{-1}$ & Present study \\
\hline Carbon per cell of Prochlorococcus & $\mathrm{CPC}_{\mathrm{p}}$ & $35.4 \mathrm{fg} \mathrm{C}$ cell $^{-1}$ & $\begin{array}{l}\text { Blanchot et al. (2001), } \\
\text { Claustre et al. (2002), } \\
\text { Bertilsson et al. (2003), } \\
\text { Heldal et al. (2003) }\end{array}$ \\
\hline Carbon-normalized yields of amino acids in detritus & $\mathrm{AA}_{\text {detritus }}$ & $10-20 \%$ & $\begin{array}{l}\text { Siezen \& Mague (1978) } \\
\text { Sheridan et al. (2002) }\end{array}$ \\
\hline Carbon-normalized yields of amino acids in samples & $\mathrm{AA}_{\text {sample }}$ & 26 or $29 \%$ & Present study \\
\hline Carbon-normalized yields of amino acids in bacteria & $\mathrm{AA}_{\text {bacteria }}$ & $35-55 \%$ & $\begin{array}{l}\text { Amy et al. (1983), } \\
\text { Simon \& Azam (1989), } \\
\text { Kaiser \& Benner (2008) }\end{array}$ \\
\hline Biomarker concentrations in POC (<80 m depth) & $\mathrm{BM}_{\mathrm{POC}}$ & $\begin{array}{c}\text { Mur: } 0.07-0.08 \mathrm{nM} \\
\text { D-Ala: } 0.36-0.46 \mathrm{nM} \\
\text { D-Glu: } 0.20-0.27 \mathrm{nM}\end{array}$ & $\begin{array}{l}\text { Present study } \\
\text { Present study } \\
\text { Present study }\end{array}$ \\
\hline Heterotrophic bacterial abundance & $\mathrm{BA}_{\mathrm{H}}$ & & $\begin{array}{l}\text { Karner et al. (2001), } \\
\text { HOT website }\end{array}$ \\
\hline Prochlorococcus abundance & $\mathrm{BA}_{\mathrm{p}}$ & & HOT website \\
\hline $\begin{array}{l}\text { Carbon-normalized yield of biomarker in heterotrophic } \\
\text { bacteria }\end{array}$ & $\mathrm{LH}_{\text {yield }}$ & $\begin{array}{l}\text { Mur: } 29.8 \mathrm{nmol} \mathrm{mgC}-1 \\
\text { D-Ala: } 58.9 \mathrm{nmol} \mathrm{mgC}^{-1} \\
\text { D-Glu: } 48.3 \mathrm{nmol} \mathrm{mgC}^{-1}\end{array}$ & $\begin{array}{l}\text { Kaiser \& Benner (2008) } \\
\text { Kaiser \& Benner (2008) } \\
\text { Kaiser \& Benner (2008) }\end{array}$ \\
\hline Carbon-normalized yield of biomarker in Prochlorococcus & $\mathrm{LP}_{\text {yield }}$ & 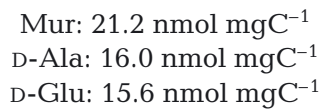 & $\begin{array}{l}\text { Kaiser \& Benner (2008) } \\
\text { Kaiser \& Benner (2008) } \\
\text { Kaiser \& Benner (2008) }\end{array}$ \\
\hline
\end{tabular}

on the website. The variability in these measurements between 1999 and 2007 at Stn ALOHA was also examined. The POC concentrations were relatively constant $\left(2.1 \pm 0.3 \mu \mathrm{mol} \mathrm{l}^{-1}\right)$ throughout all years and depths (5 to $75 \mathrm{~m}$ ), and no seasonal or annual trends were observed. $\mathrm{BA}_{\mathrm{H}}$ and the abundance of Prochlorococcus $\left(\mathrm{BA}_{\mathrm{P}}\right)$ exhibited minor seasonal variability. The abundance of $\mathrm{BA}_{\mathrm{H}}$ was slightly higher during summer (3.9 to $4.2 \times 10^{-5}$ cell ml ${ }^{-1}$ ) than in other seasons (3.2 to $3.7 \times 10^{-5}$ cell ml $\left.{ }^{-1}\right)$. The $\mathrm{BA}_{\mathrm{p}}$ was relatively high during spring $\left(0.9\right.$ to $1.4 \times 10^{-5}$ cell ml $\left.{ }^{-1}\right)$ and fall $(1.8 \times$ $10^{-5}$ cell $\mathrm{ml}^{-1}$ ); however, the overall variabilities of $\mathrm{POC}, \mathrm{BA}_{\mathrm{H}}$ and $\mathrm{BA}_{\mathrm{p}}$ are relatively small at Stn ALOHA, so the values used in this study are representative.

Carbon content of cyanobacteria, bacterial biomarker yields and cell abundance for autotrophic and heterotrophic bacteria in oceanic surface waters. Bacterial contributions to marine POM were calculated using literature values (Table 1) as well as values derived in this study. Profiles of total bacterial abundance at Stn ALOHA were obtained from the HOTS website (http://hahana.soest.hawaii.edu/hot/hot-dogs/ bextraction.html) in the upper $300 \mathrm{~m}$, and corrected for archaea using data from Karner et al. (2001). The carbon per cell of Prochlorococcus $\left(\mathrm{CPC}_{\mathrm{p}}\right)$ was estimated to be $35.4 \pm 8.9 \mathrm{fg} \mathrm{C} \mathrm{cell}^{-1}$ (range 27 to $61 \mathrm{fg} \mathrm{C}^{\mathrm{C}} \mathrm{cell}^{-1}$ ) based on several recent studies (Blanchot et al. 2001, Claustre et al. 2002, Bertilsson et al. 2003, Heldal et al. 2003). Yields of bacterial biomarkers, muramic acid (Mur), D-alanine (D-Ala) and D-glutamic acid (D-Glu), were obtained from Kaiser \& Benner (2008).

Statistical tests. A pooled $t$-test was used for all comparisons of data. A pooled standard deviation was used for values derived from more than one factor when a standard deviation or propagation error was calculated. Degrees of freedom were also considered to weight each standard deviation for the calculation of a pooled standard deviation.

\section{RESULTS}

\section{Abundance and distribution of amino acids and bacterial biomarkers, and incubation experiments, at Stn ALOHA}

Depth profiles of the concentrations of total particulate amino acids (TPAAs) and the bacterial biomarkers Mur, D-Glu and D-Ala are shown in Fig. 1. The TPAA concentrations ranged between 80 and $95 \mathrm{nmol} \mathrm{l}^{-1}$ in the upper $80 \mathrm{~m}$, and then decreased sharply to $<15 \mathrm{nmol} \mathrm{l}^{-1}$ below $500 \mathrm{~m}$ depth (Fig. 1A). The concen- 


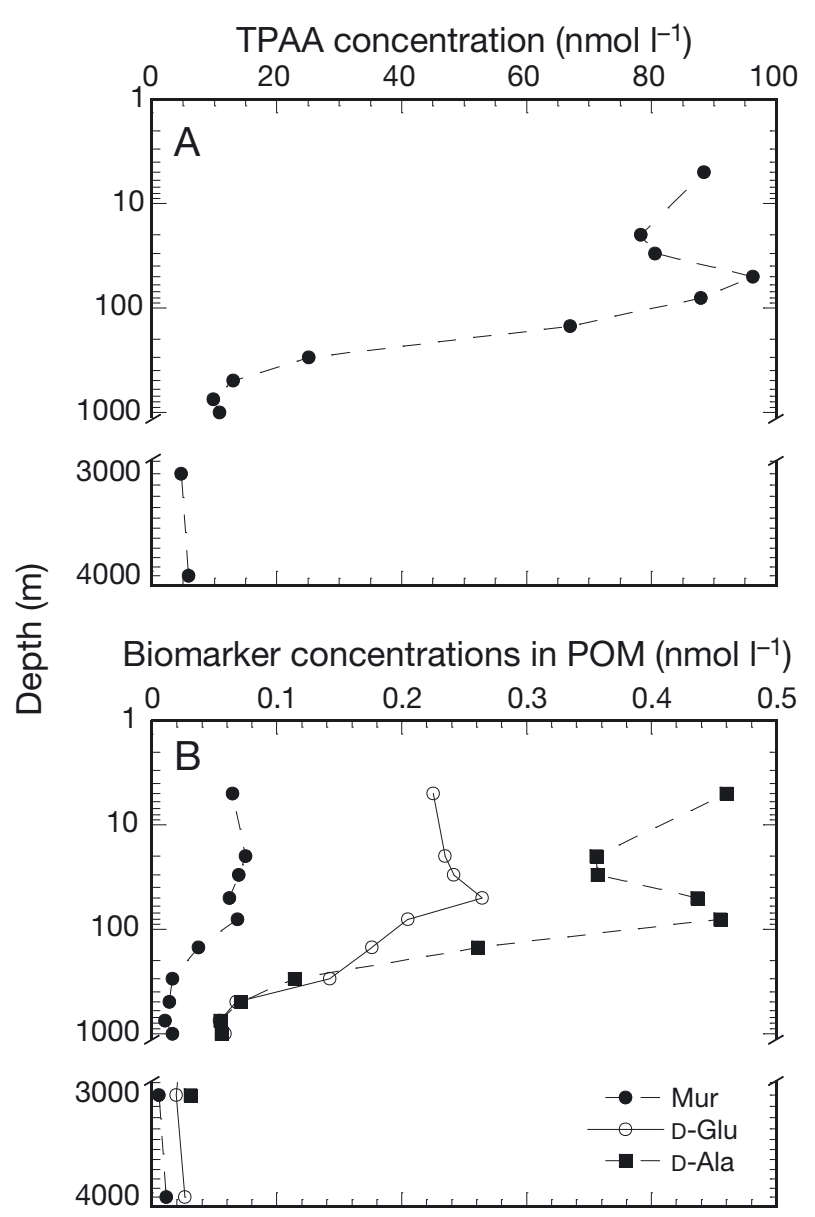

Fig. 1. Concentrations of (A) total particulate amino acids (TPAAs) and (B) muramic acid (Mur), D-alanine (D-Ala) and D-glutamic acid (D-Glu) in particulate organic matter (POM) at various depths at Stn ALOHA

trations of particulate Mur, D-Glu and D-Ala ranged from 0.06 to $0.08,0.20$ to 0.28 and 0.36 to $0.46 \mathrm{nmol} \mathrm{l}^{-1}$ in the upper $300 \mathrm{~m}$, respectively (Fig. 1B). Their concentrations decreased sharply between 300 and $1000 \mathrm{~m}$. In the deep ocean, concentrations were about 10 -fold lower than those in surface waters. In the upper $30 \mathrm{~m}$, the ratio of D-Glu to Mur was $\sim 2$, while that of DAla to Mur was over 4. Below $30 \mathrm{~m}$, both ratios were always above 3 .

Two incubation experiments ( $6 \mathrm{~d}$ each) were conducted during the cruise. Reported values represent the average and standard deviation of 3 replicate bottles in the first experiment. No growth was observed in 1 replicate bottle during the second experiment, so the average and mean deviation of the 2 other replicates is presented. The samples for cell abundance, TPAAs and particulate Mur, D-Glu and D-Ala were taken on the first and last day (Table 2). On the first day, the concentrations of particulate Mur, D-Glu and

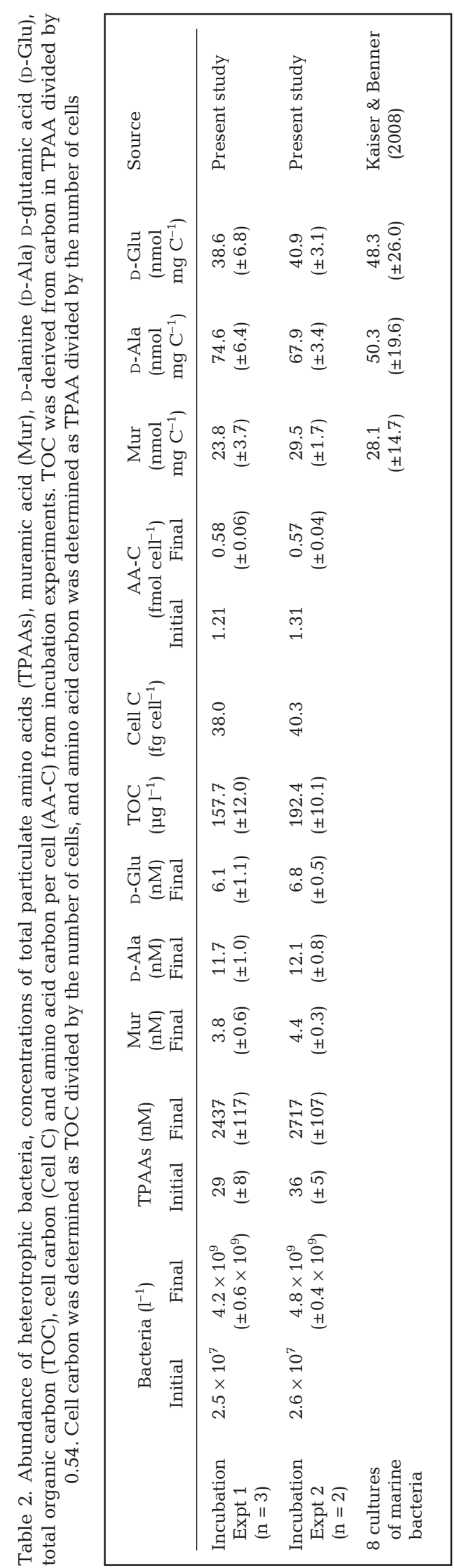


D-Ala were below detection. Bacterial cell abundance increased from $2.5 \times 10^{7}$ to $4.2 \times 10^{9}\left( \pm 0.6 \times 10^{9}\right) \mathrm{nmol}$ $\mathrm{mg} \mathrm{C}^{-1}$ and 2.6 to $4.8 \times 10^{9}\left( \pm 0.4 \times 10^{9}\right) \mathrm{l}^{-1}$ in the first and second experiments, respectively. TPAA concentrations increased from $29( \pm 8)$ to $2437( \pm 117)$ and 36 $( \pm 5)$ to $2717( \pm 107) \mathrm{nM}$ in the first and second experiments, respectively. Based on the assumptions that all particulate carbon is associated with living bacteria, and that $54 \%$ of bacterial carbon is in amino acids (Simon \& Azam 1989, Kaiser \& Benner 2008), total bacterial carbon was calculated to be $157.7( \pm 12.0)$ and $192.4( \pm 10.1) \mathrm{mg} \mathrm{C} \mathrm{l}^{-1}$ in the first and second experiments, respectively (Table 2 ). Using these values and bacterial abundance, the carbon per cell was calculated to be 38.0 and $40.3 \mathrm{fg} \mathrm{C} \mathrm{Cell}^{-1}$ in the first and second experiments, respectively. The amino acid carbon per cell (AA-C) on the initial day of the 2 experiments changed a little, ranging between 1.21 and $1.31 \mathrm{fmol} \mathrm{cell}^{-1}$, but the value was 0.57 to $0.58 \mathrm{fmol} \mathrm{cell}^{-1}$ at the end of the experiments. Carbonnormalized yields of Mur, D-Ala and D-Glu in marine bacteria from the incubation experiment were 23.8,

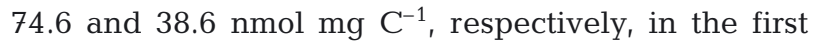

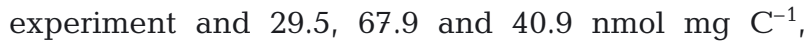
respectively, in the second experiment (Table 2). These values were not significantly different (pooled $t$-test, $\mathrm{p}>0.15)$ from those reported by Kaiser \& Benner (2008) for marine bacteria.

\section{Amino acid content of the bacterium-size fraction of marine particles}

Carbon-normalized yields of amino acids (AA-C yields) of the isolated bacterium-size fraction samples ranged from 22 to $38 \%$, with the exception of 1 value $(56 \%)$, which was not considered in the calculated average yield. Average AA-C yields of samples were $29 \pm 8 \%( \pm \mathrm{SD})$ for the open ocean and $26 \pm 4 \%$ for the coastal ocean, respectively. The average AA-C yields were lower than those of cultured cells $(\sim 54 \%)$. The range of AA-C yields of samples with a $95 \%$ confidential interval was calculated to be 15.5 to $42.5 \%$ for open ocean and 19.3 to $33.8 \%$ for coastal ocean, respectively.

\section{DISCUSSION}

\section{Carbon content of marine heterotrophic bacteria}

Previous reports of the carbon content of heterotrophic bacteria are summarized in Table 3 . The reported values are highly variable, ranging from 2 to $260 \mathrm{fg} \mathrm{C}$ cell $^{-1}$. Coastal and estuarine bacteria are generally larger and have a higher carbon content $(7$ to $260 \mathrm{fg} \mathrm{C} \mathrm{cell}{ }^{-1}$ ) than open-ocean bacteria (2 to $52 \mathrm{fg}$ $\mathrm{C}$ cell $^{-1}$ ). In addition, the values from experimental

Table 3. Summary of reported values for the carbon content of marine heterotrophic bacteria from different oceanic regions. $\mathrm{CHN}=$ carbon, hydrogen and nitrogen analysis; $\mathrm{EFM}=$ epifluorescence microscopy; $\mathrm{PC}=$ particle counting; $\mathrm{UF}=$ ultrafiltration $;$ $\mathrm{FC}=$ flow cytometry; $\mathrm{HTCO}=$ high-temperature catalytic oxidation; AA-C = carbon-normalized yield of amino acid carbon

\begin{tabular}{|c|c|c|c|c|}
\hline Sample & ncubation & Measurements & $\begin{array}{l}\text { arbon content } \\
\left(\text { fg cell }^{-1}\right)\end{array}$ & Source \\
\hline \multicolumn{5}{|l|}{ Estuary and coastal } \\
\hline Long Island Sound & Yes & CHN, EFM & $15-25$ & Lee \& Fuhrman (1987) \\
\hline Abutsubo Bay, Otsuchi Bay & Yes & $\mathrm{CHN}, \mathrm{PC}$ & $17-100$ & Kogure \& Koike (1987) \\
\hline Scripps Pier & Yes & EFM, calculation with conversion factor & $10-53$ & Simon \& Azam (1989) \\
\hline $\begin{array}{l}\text { Santa Rosa Sound, Gulf of } \\
\text { Mexico, Perido Bay }\end{array}$ & Yes & $\mathrm{CHN}, \mathrm{EFM}$ & $26-260$ & Kroer (1994) \\
\hline Norwegian fjord & No & X-ray & $7-19$ & Fagerbakke et al. (1996) \\
\hline Otsuchi Bay, Tokyo Bay & No & UF, HTCO, EFM & $16-48$ & Fukuda et al. (1998) \\
\hline Otsuchi Bay, Tokyo Bay & No & AA-C yield in isolated samples & $12.5 \pm 3.5$ & Present study \\
\hline \multicolumn{5}{|l|}{ Open ocean } \\
\hline Southern & Yes & CHN, EFM & $44-52$ & Bjørnsen \& Kuparinen (1991) \\
\hline Subtropical Pacific & No & Calculation from ATP & $2-9$ & Christian \& Karl (1994) \\
\hline $\begin{array}{l}\text { Equatorial Pacific to Southern } \\
\text { Ocean }\end{array}$ & No & UF, HTCO, EFM & $6-24$ & Fukuda et al. (1998) \\
\hline North and South Atlantic & No & $\begin{array}{l}\text { FC, calculation based upon } \\
\text { Christian \& Karl (1994) }\end{array}$ & 7 & Zubkov et al. (2000) \\
\hline Near Canary Islands & No & EFM, calculation with conversion factor & $17 \pm 26$ & Bode et al. (2001) \\
\hline Sargasso Sea & No & X-ray & $4-9$ & Gundersen et al. (2002) \\
\hline Sargasso Sea & No & CHN, EFM & 15 & Caron et al. (1995) \\
\hline North Pacific gyre & No & AA-C yield in isolated samples & $6.3 \pm 1.6$ & Present study \\
\hline
\end{tabular}


incubations are usually higher and more variable (10 to $260 \mathrm{fg} \mathrm{C} \mathrm{cell}^{-1}$ ) than those from natural samples (2 to $24 \mathrm{fg} \mathrm{C} \mathrm{cell}{ }^{-1}$ ). The glucose enrichment experiment in the present study resulted in a high bacterial carbon content (38 to $40 \mathrm{fg} \mathrm{C}^{\mathrm{C}}$ cell $^{-1}$ ) that was similar to values estimated by Bjørnsen \& Kuparinen (1991). This suggests that the carbon content per cell determined by incubation methods overestimates the carbon content of bacteria in natural environments. It has been pointed out that cultured bacteria grown in supplemented media are much larger than natural assemblages of bacteria (Lee \& Fuhrman 1987), and the size of bacteria rapidly changes during growth (Van de Merwe et al. 1997).

In this study, the carbon content of marine bacteria is derived from AA-C yields. The range of AA-C yields in particles recovered in the bacterium-size fraction was estimated to be 15.5 to $42.5 \%$ for the open ocean and 19.3 to $33.8 \%$ for the coastal ocean, respectively. These values are lower than those of cultured cells ( $\sim 50$ to $60 \%$ ) (Simon \& Azam 1989, Kaiser \& Benner 2008). This indicates that natural assemblages of bacteria could have lower AA-C yields or the isolated bacterium-size fraction included amino acid-depleted detritus, or both. Natural assemblages of bacteria are often exposed to nutrient-limited conditions, and their AA-C yields could be lower than those in cultured bacteria. However, it is unlikely that AA-C yields in natural assemblages of bacteria are highly variable because of the essential role of proteins in cellular metabolism (Amy et al. 1983, Neidhardt 1996). Therefore, it appears that the isolated bacterium-size fraction of POM contained submicron detrital particles.

It is difficult to determine precisely the AA-C yields of natural assemblages of bacteria due to the presence of detritus, but we estimated the minimal AA-C yields of bacteria using a simple 2-end member mixing model. First, we assumed 2 end members for AA$\mathrm{C}$ yields of bacteria ( $\left.\mathrm{AA}_{\text {bacteria }}\right)$ and detritus $\left(\mathrm{AA}_{\text {detritus }}\right)$. $\mathrm{AA}_{\text {bacteria }}$ was assumed to range from 35 to $55 \%$ (Amy et al. 1983, Simon \& Azam 1989), and we used $\mathrm{AA}_{\text {detritus }}$ obtained from Siezen \& Mague (1978) and Sheridan et al. (2002). Because AA-C yields measured in the water column comprised a mixture of living and detrital origins, we assumed that AA-C yields from $>500 \mathrm{~m}$ were mostly of detrital origin. Based on the literature, the $\mathrm{AA}_{\text {detritus }}$ was assumed to be 10 to $20 \%$. The range of values for the carbon content of bacteria can be estimated by assuming representative AA-C yields for bacteria and detritus. The amount of carbon and amino acids in the samples was measured, and these values for bacteria and detritus were estimated, so the carbon per cell of heterotrophic bacteria $\left(\mathrm{CPC}_{\mathrm{HB}}\right)$ could be calculated using the following formula:
$\mathrm{CPC}_{\mathrm{HB}}=\frac{12.4 \text { or } 30.4\left(\mathrm{fg} \mathrm{C}_{\text {cell }}-1\right)\left(\mathrm{AA}_{\text {sample }}-\mathrm{AA}_{\text {detritus }}\right)}{\left(\mathrm{AA}_{\text {bacteria }}-\mathrm{AA}_{\text {detritus }}\right)}$

in which all abbreviations are shown in Table 1. The values $12.4 \mathrm{fg} \mathrm{C}$ cell $^{-1}$ and $30.4 \mathrm{fg} \mathrm{C}$ cell $^{-1}$ were used as carbon per bacterial cell in the open and coastal ocean, respectively (as given in Fukuda et al. 1998). $\mathrm{AA}_{\text {detritus }}$ was assumed to range from 10 to $20 \%$ (Siezen \& Mague 1978, Sheridan et al. 2002), and AA $A_{\text {bacteria }}$ was assumed to range from 35 to 55\% (Amy et al. 1983, Simon \& Azam 1989). Cultured bacteria have fairly constant $\mathrm{AA}_{\text {bacteria }}(\sim 54 \%)$ regardless of growth conditions (Simon \& Azam 1989, Kaiser \& Benner 2008), but natural assemblages of heterotrophic bacteria are likely to be exposed to more extreme growth conditions and the carbon per cell could vary from those for cultured bacteria. The average carbon-normalized yields of samples $\left(\mathrm{AA}_{\text {sample }}\right)$ from the open and coastal oceans were 29 and $26 \%$, respectively. The $\mathrm{CPC}_{\mathrm{HB}}$ varies with different combinations of $\mathrm{AA}_{\text {bacteria }}$ and $\mathrm{AA}_{\text {detritus }}$ (Fig. 2). Our estimates of $\mathrm{CPC}_{\mathrm{HB}}$ ranged from

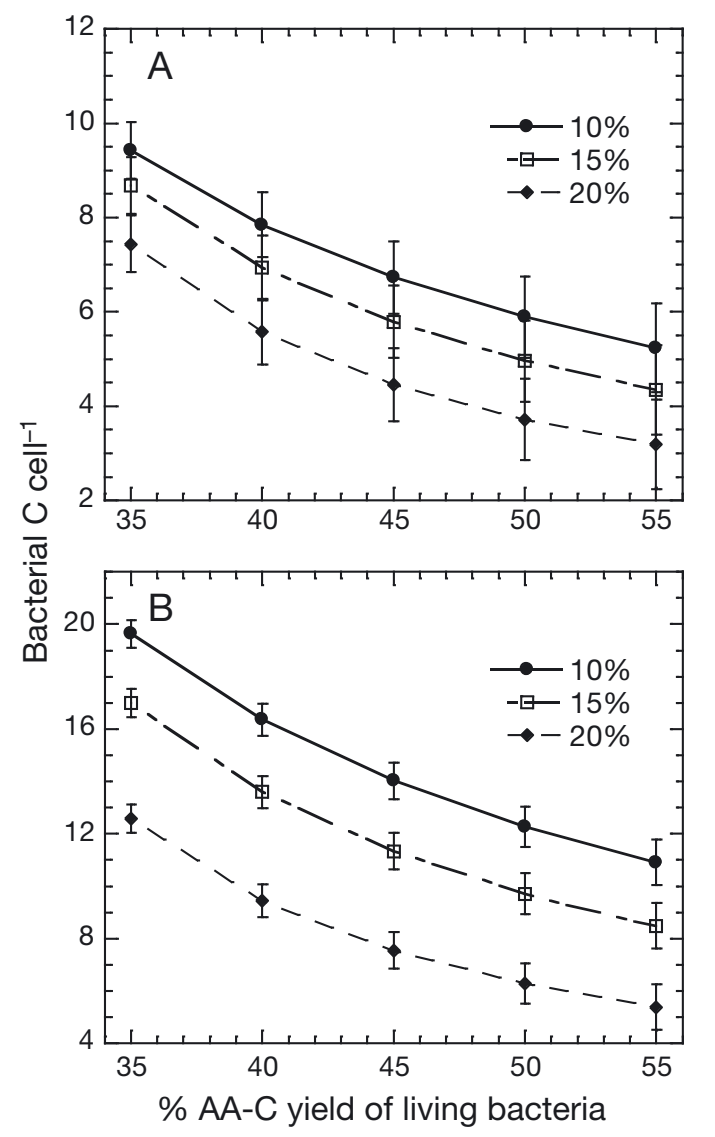

Fig. 2. Influence of varying carbon-normalized yields of amino acids (AA-C) yields (AA-C\% POC) in bacteria and detritus on calculated values of bacterial $\mathrm{C} \mathrm{cell}^{-1}$ in the open (A) and coastal (B) ocean with different AA-C yields of detritus $(10,15 \& 20 \%)$. Error bars are standard deviations $(n=3$ or 4$)$. 
3.2 to $9.4 \mathrm{fg} \mathrm{C}^{\mathrm{C}} \mathrm{cell}^{-1}$ for open ocean bacteria and from 5.4 to $19.6 \mathrm{fg} \mathrm{C} \mathrm{cell}^{-1}$ for coastal ocean bacteria. These values could overestimate $C$ cell $^{-1}$ because it is unlikely that natural marine bacteria have AA-C yields as low as $35 \%$ (Amy et al. 1983).

Assuming that the AA-C yields of marine heterotrophic bacteria follow a normal distribution, and $95 \%$ of heterotrophic bacteria possess AA-C yields between 35 and $55 \%$, the median value for the carbon content of heterotrophic bacteria was $6.3 \mathrm{fg} \mathrm{C} \mathrm{Cell}^{-1}$ in the open ocean and $12.5 \mathrm{fg} \mathrm{C}^{\mathrm{C}}$ cell $^{-1}$ in the coastal ocean. The standard deviation of the carbon content of heterotrophic bacteria was calculated using the normal distribution model. For the normal distribution, the peak width or variability of the distribution is determined by variance or standard deviation. If we assume the standard normal distribution, the width of 2 (or 1.96) standard deviations away from the median covers $95 \%$ of the phenomenon. Because we assumed that 95\% of marine bacteria possess AA-C yields between 35 and $55 \%$, the corresponding standard deviation of $\mathrm{CPC}_{\mathrm{HB}}$ was calculated to be 1.6 and $3.5 \mathrm{fg} \mathrm{C}^{-1} \mathrm{Cell}^{-1}$ for the open and costal ocean, respectively. Therefore, the values of $\mathrm{CPC}_{\mathrm{HB}}\left(6.3 \pm 1.6 \mathrm{fg} \mathrm{C} \mathrm{cell}^{-1}\right.$ for open ocean and $12.5 \pm$ $3.5 \mathrm{fg} \mathrm{C} \mathrm{cell}{ }^{-1}$ ) represent $95 \%$ of marine heterotrophic bacteria. The present estimate of the carbon content of heterotrophic bacteria ( $6.3 \mathrm{fg} \mathrm{C} \mathrm{cell}{ }^{-1}$ ) is about half of the value presented by Fukuda et al. (1998), but is similar to values presented in several studies of the carbon content of oceanic bacteria (Christian \& Karl 1994, Zubkov et al. 2000, Gundersen et al. 2002). Christian \& Karl (1994) measured biomass indicators such as chlorophyll a, ATP and prokaryotic cell counts and used a least squares inverse method with a simple linear model derived from ratios of these values to estimate the carbon per cell for phytoplankton and heterotrophic bacteria. They found that the carbon per cell for heterotrophic bacteria at Stn ALOHA was less than $10 \mathrm{fg} \mathrm{C} \mathrm{Cell}^{-1}$. Gundersen et al. (2002) reported that the carbon content of marine bacteria at the BermudaAtlantic-Time-Series (BATS) ranged between 4 and $9 \mathrm{fg} \mathrm{C} \mathrm{Cell}^{-1}$. They used a transmission electron microscope (TEM) equipped with an X-ray detector to measure the carbon content of individual cells. These independent estimates, including those in the present study, suggest that the carbon per cell for heterotrophic bacteria in oligotrophic surface waters is likely to be $<10 \mathrm{fg} \mathrm{C} \mathrm{cell}^{-1}$.

The carbon per cell in open-ocean bacteria estimated by Fukuda et al. (1998) ranged from 5.9 and $23.5 \mathrm{fg} \mathrm{C}$ cell $^{-1}$ among different oceanic regions. In these samples, the carbon per cell in the Southern Ocean $\left(48^{\circ} \mathrm{S}\right)$ and the Equatorial Pacific was relatively low (6.5 and $5.9 \mathrm{fg} \mathrm{C} \mathrm{Cell}^{-1}$, respectively) and similar to that estimated in this study. In addition, the AA-C yields of these samples were also relatively high (38 and $54 \%$ ). This could indicate that the size and density separation techniques used by Fukuda et al. (1998) had varying degrees of success in separating bacteria from detrital particles. It is also possible that bacteria have varying amounts of carbon per cell, depending on nutritional or other conditions. The application of techniques such as X-ray microanalysis might be able to address critical questions about the variability in the carbon content of marine bacteria (Heldal et al. 1996).

The carbon per cell values presented herein were estimated using a novel approach based on AA-C yields. Cultured bacteria have fairly constant AA-C yields (Simon \& Azam 1989, Kaiser \& Benner 2008) because the protein content of cells changes proportionately with cell size and carbon content under favorable growth conditions. The variability in AA-C yields of marine bacteria growing under low carbon and nutrient conditions is not well known. Under low carbon and nutrient conditions bacteria decrease in size (Psenner \& Sommaruga 1992, Ducklow et al. 1999). The AA-C yields in small cells could be lower than those in large cells because the relative contributions of nucleic acids and membranes to cell carbon could increase.

Amy et al. (1983) examined the chemical composition of bacteria under varying nutritional conditions and found that the amount of protein per cell decreased significantly after the first week of starvation but remained constant during continued starvation. The protein content of cells decreased 35 to $40 \%$ from initial values, but the size and carbon content of cells were not measured. If the carbon content of bacteria did not change during starvation, the AA-C yields of starved bacteria were $\sim 35 \%$. Decreases in the size and carbon content of bacteria are expected, so the AA-C yields of starved bacteria are likely to be $>35 \%$. Therefore, the range of AA-C yields (35 to $55 \%$ ) used in this study should be representative of values for natural assemblages of marine bacteria.

It is interesting to consider the theoretical minimal size of bacteria and other microorganisms. Free-living organisms require a minimum of 250 to 450 proteins, along with the genes and ribosomes necessary for their synthesis (Vogel 1998, Freitas \& Merkle 2004). A sphere capable of holding this minimal molecular complement would be $250 \pm 50 \mathrm{~nm}$ in diameter, including its bounding membrane. The minimal required carbon content for a bacterium to survive is estimated to be $\sim 2 \mathrm{fg} \mathrm{C} \mathrm{cell}^{-1}$ (Freitas \& Merkle 2004). In oligotrophic regions of the ocean, organic carbon and nutrients often limit bacterial growth and production. One adaptation of bacteria in these conditions is a reduction of cell size to minimize maintenance energy demand and to maximize the surface-to-volume ratio to facilitate 
transport of soluble substrates (Joint et al. 2002). It appears that most heterotrophic bacteria in the open ocean have a carbon content that is 2 to 4 times that of the theoretical minimum.

\section{Percentages of biomarkers in living bacteria and detritus}

The percentage of each biomarker (Mur, D-Ala and D-Glu) associated with living bacteria and detritus was calculated using the following formulas:

$$
\begin{aligned}
& \mathrm{BM}_{\mathrm{LH}}(\%)=\frac{\mathrm{LH}_{\text {yield }} \times \mathrm{CPC}_{\mathrm{HB}} \times \mathrm{BA}_{\mathrm{H}}}{\mathrm{BM}_{\mathrm{POC}}} \times 100 \\
& \mathrm{BM}_{\mathrm{LP}}(\%)=\frac{\mathrm{LP}_{\text {yield }} \times \mathrm{CPC}_{\mathrm{P}} \times \mathrm{BA}_{\mathrm{P}}}{\mathrm{BM}_{\mathrm{POC}}} \times 100
\end{aligned}
$$

in which $\mathrm{BM}_{\mathrm{LH}}$ and $\mathrm{BM}_{\mathrm{LP}}$ are the percentages of biomarker in living heterotrophic bacteria and Prochlorococcus, respectively, $\mathrm{LH}_{\text {yield }}$ and $\mathrm{LP}_{\text {yield }}$ are carbonnormalized yields of each biomarker in heterotrophic bacteria and Prochlorococcus, respectively, $\mathrm{CPC}_{\mathrm{HB}}$ and $\mathrm{CPC}_{\mathrm{P}}$ are the carbon per cell of heterotrophic bacteria and Prochlorococcus, respectively, $\mathrm{BM}_{\mathrm{POC}}$ is the concentration of each biomarker in $\mathrm{POC}$, and $\mathrm{BA}_{\mathrm{H}}$ and $\mathrm{BA}_{\mathrm{P}}$ are the abundance of heterotrophic bacteria and Prochlorococcus, respectively (see abbreviations and values in Table 1). The average range of 3 biomarkers for $\mathrm{BM}_{\mathrm{LH}}$ and $\mathrm{BM}_{\mathrm{LP}}$ was 30 to $55 \%$ and 25 to $60 \%$ in the upper $80 \mathrm{~m}$, respectively (Fig. 3A \& B). Thus, a large percentage of the biomarkers ( 70 to $90 \%$ ) was associated with living bacteria in surface waters. The average $\mathrm{BM}_{\mathrm{LH}}$ decreased dramatically with depth, and below $1000 \mathrm{~m}<10 \%$ of the biomarkers were associated with living bacteria.

\section{Contributions of living bacteria and bacterial detritus to POC}

The contributions of living bacteria to suspended POC at Stn ALOHA were estimated from the carbon content of bacteria and cell abundance. The detrital contributions of bacteria to suspended POC were calculated as the difference between the amount of each biomarker in POC and living bacteria. Because bacterial detritus is derived from both autotrophic and heterotrophic bacteria, the bacterial detritus originating from heterotrophic bacteria was assumed to contain the same carbon-normalized yields of biomarkers as heterotrophic bacteria. The same assumption was made for the bacterial detritus from autotrophic bacteria. Contributions of living heterotrophic and auto-

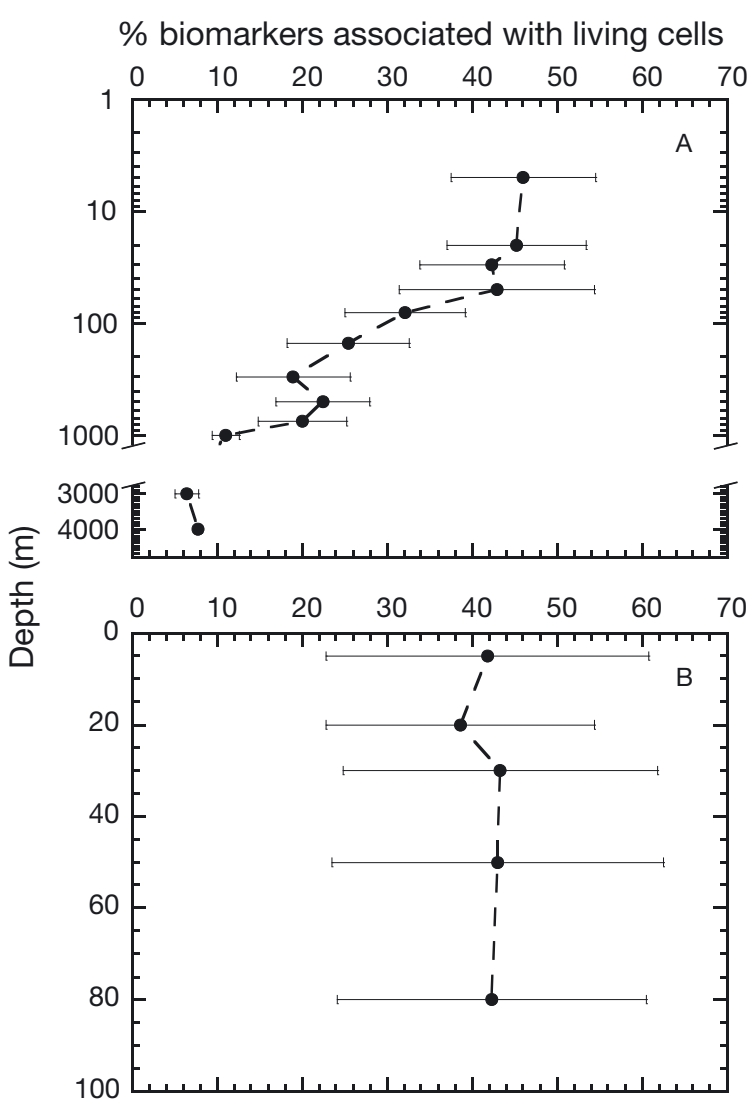

Fig. 3. Average percentages of measured biomarkers in bacteria at Stn ALOHA. (A) Heterotrophic bacteria throughout the water column, and (B) autotrophic bacteria in the surface waters. Error bars are standard deviations $(\mathrm{n}=3)$

trophic bacteria to suspended POC at Stn ALOHA were calculated using the following formulas:

$$
\begin{aligned}
& \mathrm{LH}(\%)=\frac{\left(\mathrm{BA}_{\mathrm{H}} \times \mathrm{CPC}_{\mathrm{HB}}\right) \div 12}{\mathrm{POC}} \times 100 \\
& \mathrm{LP}(\%)=\frac{\left(\mathrm{BA}_{\mathrm{H}} \times \mathrm{CPC}_{\mathrm{HB}}\right) \div 12}{\mathrm{POC}} \times 100
\end{aligned}
$$

in which LH and LP are contributions of living heterotrophic bacteria and living Prochlorococcus to suspended $\mathrm{POC}$, respectively, $\mathrm{BA}_{\mathrm{H}}$ and $\mathrm{BA}_{\mathrm{P}}$ are the abundance of heterotrophic bacteria and Prochlorococcus, respectively, and $\mathrm{CPC}_{\mathrm{HB}}$ and $\mathrm{CPC}_{\mathrm{P}}$ are the carbon per cell of heterotrophic bacteria and Prochlorococcus, respectively (see abbreviations and values in Table 1). Contributions of bacteria to detritus were calculated using the following formula from Kaiser \& Benner (2008):

$$
\mathrm{BC}(\%)=\frac{\text { Biomarker }_{\mathrm{POM}}}{\text { Biomarker }_{\text {bacteria }}} \times 100
$$


in which $\mathrm{BC}$ is the contribution of bacterial carbon to suspended POC, and Biomarker ${ }_{\mathrm{POM}}$ and Biomarker bacteria $_{\text {B }}$ are the carbon-normalized yields of a specific biomarker in POC and living bacteria, respectively. The yields of biomarkers in bacteria were obtained from the 3 phototrophic and 5 heterotrophic marine bacteria (Kaiser \& Benner 2008) assuming a mixture of $70 \%$ heterotrophic bacteria and 30\% autotrophic bacteria.

These calculations indicated that LH and LP accounted for 5.2 to $8.2 \%$ (average $6.8 \pm 1.1 \%$ ) and 12.4 to $14.2 \%$ (average $13.3 \pm 2.2 \%$ ) of POC, respectively (Fig. 4). The range of $\mathrm{BC}$ contributions to POC was 22.2 to $25.8 \%$ (average $24.4 \pm 6.4 \%$ ). The contributions of bacterial detritus to suspended POC in the surface ocean at Stn ALOHA were calculated by subtracting the sum of LH and LP from BC. The contribution of bacterial detritus to POC ranged from 2.5 to $6.9 \%$ (average $4.3 \pm 2.9 \%$ ) in surface waters (Fig. 4 ). The cumulative errors on this calculation followed the law of error propagation.

The estimated living heterotrophic bacterial contribution to suspended POC $(6.8 \pm 1.1 \%)$ in this study is

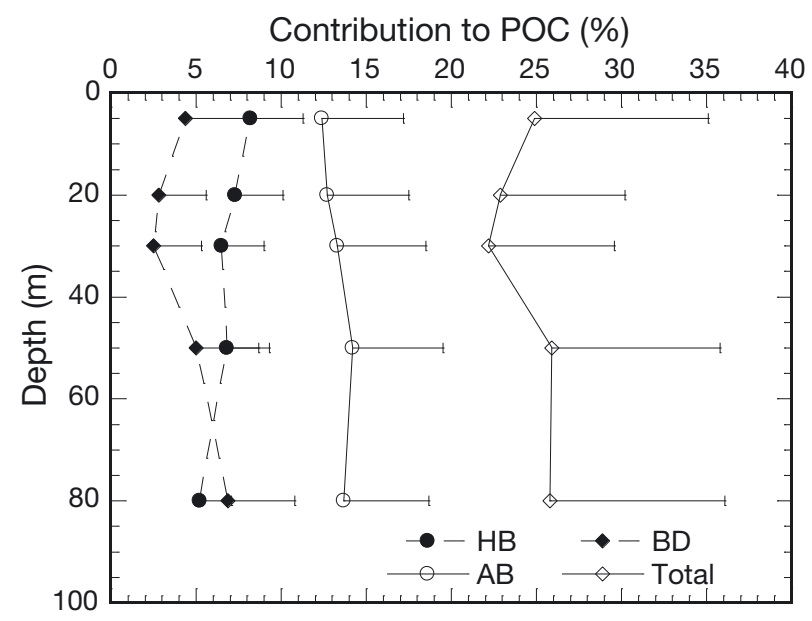

Fig. 4. Relative contributions of heterotrophic bacteria (HB), autotrophic bacteria (AB), bacterial detritus (BD) and their total $(\mathrm{HB}+\mathrm{AB}+\mathrm{BD})$ to suspended POC in the surface waters of the ocean at Stn ALOHA. Error bars are standard deviations $(\mathrm{n}=3$ or 9$)$

Table 4. Estimated contributions of living heterotrophic bacteria to particulate organic carbon (POC) in surface waters of the oligotrophic ocean

\begin{tabular}{|lccl|}
\hline Sample & $\begin{array}{c}\text { Carbon content } \\
\left(\text { fg cell }^{-1} \text { ) }\right.\end{array}$ & $\begin{array}{c}\text { \% POC as } \\
\text { living bacteria }\end{array}$ & Source \\
\hline North Pacific gyre & 20 & 40 & Cho \& Azam (1988) \\
Sargasso Sea & 15 & $10-20$ & Caron et al. (1995) \\
Sargasso Sea & 10 & $14-19$ & Gundersen et al. (2001) \\
North Pacific gyre & 6.3 & $5.2-8.2$ & Present study \\
\hline
\end{tabular}

much lower than estimates (10 to $40 \%$ ) presented in previous studies (Cho \& Azam 1988, Caron et al. 1995, Gundersen et al. 2001) (Table 4). Differences among these estimates are due largely to the presumed carbon content of bacteria. Therefore, it is crucial to establish accurate values for the carbon content of marine bacteria to understand bacterial contributions to oceanic biogeochemical cycles.

The present study showed the relative contributions of heterotrophic and autotrophic bacteria and bacterial detritus to suspended POC. Kaiser \& Benner (2008) estimated total bacterial contributions (living and detritus) to suspended POC at Stn ALOHA to be 28 to $32 \%$, which was similar to the value estimated in this study $(24.4 \pm 6.4 \%)$. The contribution of bacterial detritus to suspended POC increased with depth at Stn ALOHA and is an abundant component of suspended POC in deep waters (Benner \& Kaiser 2003, Shibata et al. 2006, Kaiser \& Benner 2008, present study). Koike et al. (1990) and Longhurst et al. (1992) estimated that submicron particles were a dominant component of suspended POC, and, based on the present and previous studies, it appears that bacteria are a source of these submicron detrital particles.

The contribution of autotrophic bacteria to suspended POC was estimated to be $\sim 13 \%$, which is about 2 times greater than the estimated heterotrophic bacterial contribution. In contrast, Campbell et al. (1994) reported that the relative contributions of autotrophic and heterotrophic bacteria to total biomass were similar in surface waters at Stn ALOHA. The difference between our studies is due largely to the use of different values for the carbon content of heterotrophic bacteria. The carbon content for heterotrophic bacteria (20 fg $\mathrm{C} \mathrm{cell}^{-1}$ ) used by Campbell et al (1994) was $~ 3$ times greater than the value $\left(6.3 \mathrm{fg} \mathrm{C} \mathrm{cell}^{-1}\right)$ used in the present study.

The relative contributions of living heterotrophic and autotrophic bacteria to suspended POC in surface waters appear to vary among oligotrophic regions of the global ocean. For example, Synechococcus dominates autotrophic bacterial abundance in the Sargasso Sea, and because Synechococcus is several times larger than Prochlorococcus (Blanchot et al. 2001), the contribution of cyanobacteria to suspended POC in this region could be even higher than at Stn ALOHA.

The estimated contributions of heterotrophic and autotrophic bacteria as well as bacterial detritus to POC in this study could be overestimated because literature- derived POC values were obtained using GF/F filters $(0.7 \mu \mathrm{m}$ nominal pore size), whereas Supor filters $(0.2 \mu \mathrm{m}$ pore size) were used in 
this study to estimate bacterial contributions. In the oligotrophic ocean, POC concentrations obtained using GF/F filters can be $30 \%$ lower than those obtained using aluminum oxide filters with a pore size of $0.2 \mu \mathrm{m}$ (Altabet 1990). Therefore, maximal estimates of bacterial contributions to POC are presented in this study.

The present study, and that of Benner \& Kaiser (2003), indicate that the ratio of bacterial detrital carbon to living carbon increases dramatically with depth. Biomarkers associated with living heterotrophic bacteria decreased from $30-50 \%$ in surface waters to $<10 \%$ in the deep ocean. Grazing (Nagata 2000), viral infection (Weinbauer 1994) and enzymatic hydrolysis (Nagata \& Kirchman 1996) play important roles in the fate of bacteria and the production of bacterial detritus. The vertical distribution of bacterial detritus in the ocean provides some insight into the reactivity of this material. It appears that there is a substantial bacterial component of suspended POC in the deep ocean that is resistant to decomposition.

Acknowledgements. We thank M. B. Karner for providing bacterial abundance data, K. Kaiser for laboratory assistance and advice, and A. Shibata for useful comments on this manuscript. We thank the scientists and crew aboard the R/V 'Kilo Moana' for assistance with sampling. This research was supported by grants EAR 0120579 and OCE 0080782 from the National Science Foundation.

\section{LITERATURE CITED}

Altabet MA (1990) Organic C, N, and stable isotopic composition of particulate matter collected on glass-fiber and aluminum oxide filters. Limnol Oceanogr 35:902-909

Amy PS, Pauling C, Morita RY (1983) Starvation-survival processes of a marine Vibrio. Appl Environ Microbiol 45: 1041-1048

Benner R, Kaiser K (2003) Abundance of amino sugars and peptidoglycan in marine particulate and dissolved organic matter. Limnol Oceanogr 48:118-128

Bertilsson S, Berglund O, Karl DM, Chisholm SW (2003) Elemental composition of marine Prochlorococcus and Synechococcus: implications for the ecological stoichiometry of the sea. Limnol Oceanogr 48:1721-1731

Bjørnsen PK, Kuparinen J (1991) Determination of bacterioplankton biomass, net production and growth efficiency in the Southern Ocean. Mar Ecol Prog Ser 71: 185-194

Blanchot J, Andre JM, Navarette C, Neveux J, Radenae MH (2001) Picophytoplankton in the equatorial Pacific: vertical distributions in the warm pool and in the high nutrient low chlorophyll conditions. Deep-Sea Res 48:297-314

Bode A, Barquero S, Varela M, Braun JG, de Armas D (2001) Pelagic bacteria and phytoplankton in oceanic waters near the Canary Islands in summer. Mar Ecol Prog Ser 209:1-17

Campbell L, Nolla HA, Vaulot D (1994) The importance of Prochlorococcus to community structure in the central North Pacific Ocean. Limnol Oceanogr 39:954-961
Caron DA, Dam HG, Kremer P, Lessard EJ and others (1995) The contribution of microorganisms to particulate carbon and nitrogen in surface waters of the Sargasso Sea near Bermuda. Deep-Sea Res 42:943-972

Cho BC, Azam F (1988) Major role of bacteria in biogeochemical fluxes in the ocean's interior. Nature 332:441-443

> Christian J, Karl D (1994) Microbial community structure at the US-JGOFS station ALOHA: inverse methods for estimating biochemical indicator ratios. J Geophys Res 99: 14269-14276

> Claustre H, Bricaud A, Babin M, Bruyant F, Guillou L, Le Gall F, Marie D, Partensky F (2002) Diel variation in Prochlorococcus optical properties. Limnol Oceanogr 47:1637-1647

> Davis J, Kaiser K, Benner R (2009) Amino acid and amino sugar yields and compositions as indicators of dissolved organic matter diagenesis. Org Geochem 40:343-352

Ducklow HW (2000) Bacterial production and biomass in the oceans. In: Kirchman DL (ed) Microbial ecology of the oceans. John Wiley, New York, NY, p 85-120

Fagerbakke KM, Heldal M, Norland S (1996) Content of carbon, nitrogen, oxygen, sulfur and phosphorus in native aquatic and cultured bacteria. Aquat Microb Ecol 10: $15-27$

Fogg GE (1986) Picoplankton. Proc R Soc Lond B Biol Sci 228:1-30

Freitas RA, Merkle RC (2004) Kinematic self-replicating machines. Landes Bioscience, Georgetown, TX

Fuhrman JA, Sleeter TD, Carlson CA, Proctor LM (1989) Dominance of bacterial biomass in the Sargasso Sea and its ecological implications. Mar Ecol Prog Ser 57:207-217

Fukuda R, Ogawa H, Nagata T, Koike I (1998) Direct determination of carbon and nitrogen contents of natural bacterial assemblages in marine environments. Appl Environ Microbiol 64:3352-3358

Gundersen K, Orcutt KM, Purdie DA, Michaels AF, Knap AH (2001) Particulate organic carbon mass distribution at the Bermuda Atlantic Time-series Study (BATS) site. DeepSea Res 48:1697-1718

> Gundersen K, Heldal M, Norland S, Purdie DA, Knap AH (2002) Elemental C, N, and P cell content of individual bacteria collected at the Bermuda Atlantic Time-series Study (BATS) site. Limnol Oceanogr 47:1525-1530

> Heldal M, Norland S, Fagerbakke KM, Thingstad F, Bratbak G (1996) The elemental composition of bacteria: a signature of growth conditions? Mar Pollut Bull 33:3-9

Heldal M, Scanlan DJ, Norland S, Thingstad F, Mann NH (2003) Elemental composition of single cells of various strains of marine Prochlorococcus and Synechococcus using X-ray microanalysis. Limnol Oceanogr 48: 1732-1743

HOT station report (2004) (http://hahana.soest.hawaii.edu/ hot/hot-dogs/bextraction.html)

> Joint I, Henriksen P, Fonnes GA, Bourne D, Thingstad TF, Riemann B (2002) Competition for inorganic nutrients between phytoplankton and bacterioplankton in nutrient manipulated mesocosms. Aquat Microb Ecol 29:145-159

Kaiser K, Benner R (2005) Hydrolysis-induced racemization of amino acids. Limnol Oceanogr Methods 3:318-325

Kaiser K, Benner R (2008) Major bacterial contribution to the ocean reservoir of detrital organic carbon and nitrogen. Limnol Oceanogr 53:99-112

- Kana TM, Glibert PM (1987) Effect of irradiances up to 2000 $\mathrm{FE} \mathrm{m} \mathrm{m}^{-2} \mathrm{~s}^{-1}$ on marine Synechococcus WH7803. 1. Growth, pigmentation, and cell composition. Deep-Sea Res 34: 479-495

Karner MB, DeLong EF, Karl DM (2001) Archaeal dominance in the mesopelagic zone of the Pacific Ocean. Nature 409: $507-510$ 
Keil RG, Kirchman DL (1991) Dissolved combined aminoacids in marine waters as determined by a vapor-phase hydrolysis method. Mar Chem 33:243-259

Kogure K, Koike I (1987) Particle counter determination of bacterial biomass in seawater. Appl Environ Microbiol 53: $274-277$

Koike I, Hara S, Terauchi K, Kogure K (1990) Role of submicrometre particles in the ocean. Nature 345:242-243

Kroer N (1994) Relationships between biovolume and carbon and nitrogen content of bacterioplankton. FEMS Microbiol Ecol 13:217-223

Lee S, Fuhrman JA (1987) Relationship between biovolume and biomass of naturally derived marine bacterioplankton. Appl Environ Microbiol 53:1298-1303

Letelier RM, Bidigare RR, Hebel DV, Ondrusek M, Winn CD, Karl DM (1993) Temporal variability of phytoplankton community structure based on pigment analysis. Limnol Oceanogr 38:1420-1437

Lindroth P, Mopper K (1979) High-performance liquidchromatographic determination of subpicomole amounts of amino-acids by precolumn fluorescence derivatization with ortho-phthaldialdehyde. Anal Chem 51: 1667-1674

Liu H, Campbell L, Landry MR (1995) Growth and mortality rates of Prochlorococcus and Synechococcus measured with a selective inhibitor technique. Mar Ecol Prog Ser 68: 85-99

Longhurst AR, Koike I, Li WKW, Rodriguez J and others (1992) Submicron particles in northwest Atlantic shelf water. Deep-Sea Res 39:1-7

McCarthy MD, Hedges JI, Benner R (1998) Major bacterial contribution to marine dissolved organic nitrogen. Science 281:231-234

Nagata T (2000) Production mechanisms of dissolved organic matter. In: Kirchman DL (ed) Microbial ecology of the oceans. John Wiley, New York, NY, p 121-152

Editorial responsibility: Gerhard Herndl,

Vienna, Austria
Nagata T, Kirchman DL (1996) Bacterial degradation of protein adsorbed to model submicron particles in seawater. Mar Ecol Prog Ser 132:241-248

Neidhardt FC (1996) Escherichia coli and Salmonella: cellular and molecular biology. American Society for Microbiology Press, Washington DC

Partensky F, Hess WR, Vaulot D (1999) Prochlorococcus, a marine photosynthetic prokaryote of global significance. Microbiol Mol Biol Rev 63:106-127

Porter KG, Feig YS (1980) The use of DAPI for identifying and counting aquatic microflora. Limnol Oceanogr 25:943-948

Psenner R, Sommaruga R (1992) Are rapid changes in bacterial biomass caused by shifts from top-down to bottomdown control? Limnol Oceanogr 37:1092-1100

Sheridan CC, Lee C, Wakeham SC, Bishop JKB (2002) Suspended particle organic composition and cycling in surface and midwaters of the equatorial Pacific Ocean. DeepSea Res 49:1983-2008

Shibata A, Ohwada K, Tsuchiya M, Kogure K (2006) Particulate peptidoglycan in seawater determined by the silkworm larvae plasma (SLP) assay. J Oceanogr 62:91-97

> Siezen RJ, Mague TH (1978) Amino acids in suspended particulate matter from oceanic and coastal waters of the Pacific. Mar Chem 6:215-231

Simon M, Azam F (1989) Protein content and protein synthesis rates of planktonic marine bacteria. Mar Ecol Prog Ser 51:201-213

Van de Merwe WP, Li ZZ, Bronk BV, Czégé J (1997) Polarized light scattering for rapid observation of bacterial size changes. Biophys J 73:500-506

Vogel G (1998) Finding life's limits. Science 282:1399

Weinbauer MG (1994) Ecology of prokaryotic viruses. FEMS Microbiol Rev 28:127-181

Zubkov MV, Sleigh MA, Burkill PH, Leakey RJG (2000) Bacterial growth and grazing loss in contrasting areas of North and South Atlantic. J Plankton Res 22:685-711

Submitted: December 19, 2008; Accepted: September 28, 2010 Proofs received from author(s): December 10, 2010 